\title{
Response of mussel Brachidontes striatulus to chlorination: An experimental study
}

Article in Aquatic Toxicology · September 1997

DOI: $10.1016 /$ S0166-445X(97)00021-0

\section{CITATIONS}

42

4 authors, including:

Sanjeevi Rajagopal

Radboud University

69 PUBLICATIONS 2,785 CITATIONS

SEE PROFILE

Henk A. Jenner

Aquator B.V.

82 PUBLICATIONS 2,557 CITATIONS

SEE PROFILE

\section{READS}

151

Gerard Van der Velde

Radboud University

421 PUBLICATIONS 17,067 CITATIONS

SEE PROFILE

Some of the authors of this publication are also working on these related projects:

Project $\quad$ British EDFE Estuarine and Marine Studies (BEEMS) View project

Life history and feeding strategies of selected, alien gammarid species (Crustacea: Amphipoda) in Polish waters View project 


\title{
Response of mussel Brachidontes striatulus to chlorination: an experimental study
}

\author{
S. Rajagopal ${ }^{a, *}$, K.V.K. Nair ${ }^{b}$, G. van der Velde ${ }^{c}$, H.A. Jenner ${ }^{d}$ \\ ${ }^{a}$ Department of Zoology, University of Madras, Guindy Campus, Madras 600 025, India \\ ${ }^{b}$ Water and Steam Chemistry Laboratory (APCD, BARC). Indira Gandhi Centre for Atomic Research, \\ Kalpakkam 603 102, India \\ 'Department of Ecology, Laboratory of Aquatic Ecology, Faculty of Science, University of Nijmegen, \\ Toernooiveld, 6525 ED Nijmegen, The Netherlands \\ ${ }^{\mathrm{d}}$ KEMA Environmental Research, P.O. Box 9035, 6800 ET Arnhem. The Netherlands
}

Accepted 14 January 1997

\begin{abstract}
Though the brackish-water mussel, Brachidontes striatulus (Hanley) (syn. Modiolus striatulus) is an important fouling animal in power station cooling circuits, there are no published studies on the tolerance of this species to chlorination. Mortality pattern as well as physiological behaviour (byssus thread production, foot activity index and filtration rate) of three different size groups (7,18 and $25 \mathrm{~mm}$ shell length) of $B$. striatulus, were studied at different chlorine concentrations ( $0-5 \mathrm{mg} \mathrm{l}^{-1}$ ). At $1 \mathrm{mg} \mathrm{l}^{-1}$ chlorine residual, $7 \mathrm{~mm}$ size group mussels showed 100\% mortality in $468 \mathrm{~h}$ (20 days) and $25 \mathrm{~mm}$ size group mussels in $570 \mathrm{~h}$ ( 24 days). At relatively high levels of chlorine residuals $\left(5 \mathrm{mg}^{-1}\right), 100 \%$ mortality in 7 and $25 \mathrm{~mm}$ size groups took 102 and $156 \mathrm{~h}$, respectively. The exposure time to chlorine required for $100 \%$ mortality of $B$. striatulus is much lower than that reported for some other common fouling mussels. Chlorine concentration significantly affected the mean time of death for all size groups of mussels. All size groups showed progressive reduction in physiological activities such as filtration rate, foot activity index and byssus thread production when chlorine residuals were increased from 0 to $1.5 \mathrm{mg} \mathrm{l}^{-1}$. Reduction in physiological activities of mussels was strongly correlated with the concentration of chlorine. (c) 1997 Elsevier Science B.V.
\end{abstract}

Keywords: Power plant; Biofouling; Control measures; Chlorination; Mortality; Brachidontes striatulus; Physiological functions

\section{Introduction}

Biofouling in cooling water systems of coastal power plants is a well known

*Corresponding author. Department of Ecology, Laboratory of Aquatic Ecology, Facully of Science, University of Nijmegen, Toernooiveld, 6525 ED Nijmegen, The Netherlands. Fax. (+31-24) 3652134. 
problem (Mattice and Zittel, 1976; Khalanski and Bordet, 1980; Rajagopal, 1991). Sessile mussels are often a major fouling species in power plant cooling systems where their settlement and growth result in blockage of free flow of water in the conduits (Rajagopal et al., 1991) and clogging of condenser tubes (Holmes, 1970). To discourage settlement of mussels, chlorine is commonly used as it is both effective and economical (Lewis, 1985). However, owing to increasing concern about toxicity of chlorine by-products to aquatic life, several countries are making efforts to minimize chlorine residuals in the discharges (Post et al., 1985; Jenner, 1985; Fisher et al., 1991; Bidwell et al., 1995). A study of response of various mussel species to chlorine has great importance from the point of optimization of chlorine treatments in cooling systems (Lewis, 1985).

In tropical power stations, though larger mussels like Perna viridis (L.) and $P$. indica Kuriakose and Nair are conspicuous in terms of biomass, smaller mussels like Brachidontes striatulus (Hanley), Modiolus modiolus sensu auct. and M. philippinarum (Hanley) are numerically important (Morton, 1977; Rajagopal et al., 1991). B. striatulus was also reported to foul Visakhapatnam harbour and various docks of Calcutta (Morton, 1977). The objective of this study was to understand the lethal and sublethal effects of chlorine on different size groups of B. striatulus, a major foulant at Madras Atomic Power Station.

\section{Materials and methods}

\subsection{Description of the study area}

Madras Atomic Power Station (MAPS), situated at Kalpakkam $\left(12^{\circ} 33^{\prime} \mathrm{N} \&\right.$ $80^{\circ} 11^{\prime} \mathrm{E}$ ), about $65 \mathrm{~km}$ south of Madras, on the east coast of India, uses chlorine to control fouling in the seawater cooling conduits. B. striatulus is one of the major fouling species in the sub-seabed intake tunnel of MAPS (Rajagopal et al., 1991). In Kalpakkam coastal waters, $B$. striatulus, has two spawning periods in a year: one during April-May and the other in August-September (Rajagopal, 1991). The present study was carried out during the non-spawning period of mussels (15 October 1990-30 March 1991). B. striatulus grows to $7 \mathrm{~mm}$ shell length in a month and to $25 \mathrm{~mm}$ in a year.

\subsection{Test animals}

The response of $B$. striatulus to different chlorine concentrations was studied in the laboratory, using mussels collected from coastal waters near the MAPS intake area. In the laboratory, the mussels were left undisturbed in seawater $(34.1 \pm 0.4 \%$ o salinity, $5.8 \pm 0.5 \mathrm{mg} \mathrm{l}^{-1}$ dissolved oxygen and $29.4 \pm 0.6^{\circ} \mathrm{C}$ temperature) for two days $(48 \mathrm{~h})$ to allow them to recover from the effects of stress. Animals were picked up from this stock for each experiment. 


\subsection{Mortality}

Three size groups (shell length $\pm \mathrm{SD} ; 6.9 \pm 0.2,18.9 \pm 1.2$ and $25.4 \pm 1.9 \mathrm{~mm}$ ) of mussels were tested for four different chlorine doses $\left(1,2,3\right.$ and $\left.5 \mathrm{mg} \mathrm{1}^{-1}\right)$. Seawater collected from the coastal waters was used for the experiment, after a day's storage. Factors which may change the response of mussels such as salinity, temperature, dissolved oxygen and flow rate were kept constant in each of the experimental treatments. Salinity was maintained between 33.8 and $34.3 \%$. Temperature and dissolved oxygen were maintained between 29.2 and $29.8^{\circ} \mathrm{C}$ and 5.1 and $6.5 \mathrm{mg} \mathrm{l}^{-1}$, respectively. Moreover, in preliminary experiments similar mortality responses to chlorine were observed between fed (mixed algal culture) and starved mussels (Rajagopal, 1991; Rajagopal et al., 1995). Hence, the experimental mussels were not fed during the course of the experiment. The experiments were conducted in continuous once-through flow systems, following the procedures outlined by Rajagopal et al. (1995). Seawater was stored in a 1501 aquarium tank and chlorine solution prepared from bleaching powder was stored in a 21 volumetric flask. Appropriate mixes of the two were used to maintain desired chlorine concentration in a 51 glass beaker having an outlet at the 4.51 mark, using a peristaltic pump (Buchler Instruments, Port Lee, N.J. USA, Model No. 73351). Mixing of the water was facilitated by the use of aerators. A continuous flow at a rate of $80 \mathrm{ml} \mathrm{min}^{-1}$ was maintained throughout the test. After $48 \mathrm{~h}$ of acclimation, six mussels [ 6 mussels in each experiment $) \times(3$ size groups $) \times(4$ chlorine concentrations $)=72$ mussels $]$ were introduced into the experimental tanks containing seawater of known chlorine concentration. The levels of residual chlorine were monitored at subsequent $30 \mathrm{~min}$ intervals at the outlet. Residual chlorine measurements were done using the iodometric method (White, 1972). Since the death of the mussels is often not directly observable (Jensen, 1982), mussels failing to close their shell as a response to external stimuli, when removed from water, were considered dead (Wallis, 1975). The number of dead animals in each experiment was recorded along with their shell lengths and total weights for each observation time. The same experiment was repeated two ( 1 and $2 \mathrm{mg}^{-1}$ ) to four times ( 3 and $5 \mathrm{mg} \mathrm{l}^{-1}$ ) for each size group and chlorine concentration. Altogether 216 mussels were used for the mortality experiments [ $(12$ experiments $) \times(6$ mussels in each experiment $) \times(3$ size groups $)=216$ mussels $]$.

\subsection{Sublethal responses}

Apart from this, filtration rate, foot activity index and byssus thread production of different size groups of mussels were also studied at six different chlorine doses $\left(0,0.25,0.50,0.75,1.00\right.$ and $\left.1.50 \mathrm{mg}^{-1}\right)$. Experiments were run exactly as detailed above with 10-15 mussels used in each treatment. The only difference was that the mussels were left for $24 \mathrm{~h}$ for foot activity index and byssus thread production and for $3 \mathrm{~h}$ for filtration rate studies.

Rate of filtration was measured following the method described by Coughlan (1969). The method is based on the absorption of neutral red by mussels from ambient water. The rate of filtration was calculated using the following equation 
of Coughlan (1969):

$m=\frac{M}{n t} \log \frac{C_{\mathrm{o}}}{C_{\mathrm{t}}}$

where $M$ is the volume of the test solution; $n$ is number of animals used in the experiment; $t$ is time (h); $C_{0}$ is the initial concentration of the dye; $C_{t}$ is the concentration of the dye at time $t ; m$ is the rate of filtration in $\mathrm{ml} \mathrm{h}^{-1}$ per mussel.

For foot activity index, at every $10 \mathrm{~min}$, a note was made of the number of mussels with the foot extended outside the shell (Holmes, 1970). No attempt was made to follow the foot activity of individual mussels. For each experiment, all foot activity readings were analyzed and a percentage foot activity index was calculated.

The rate of byssus thread production was determined following procedures outlined by Winkle (1970) and Allen et al. (1976). After acclimation (48 h), one mussel was placed in a 11 glass beaker (outlet at 0.751 mark) containing 0.751 of seawater of known chlorine concentration ( $n=10-15$ per size group in each chlorine dose). Use of one mussel per container eliminated the need for coding mussels and avoided the problem of counting threads when mussels clump, which they invariably do. Byssus threads produced by mussels were counted after $24 \mathrm{~h}$ and expressed in threads per mussel per day (Winkle, 1970).

\subsection{Statistical analysis}

The differences in mortality of different size groups of B. striatulus at various chlorine doses were tested by analysis of covariance (ANCOVA). The sublethal responses of different size groups of mussels to various chlorine levels were analyzed using exponential regression and statistical tests of the correlation coefficients (Sokal and Rohlf, 1981). The differences in physiological activity between control $\left(0 \mathrm{mg} \mathrm{l}^{-1}\right.$ chlorine dose) and experimental mussels $(0.25,0.50,0.75,1.00$ and $1.50 \mathrm{mg} \mathrm{l}^{-1}$ chlorine doses) were compared by Student's $t$-tests after Bonferroni corrections (Zar, 1984). The post-hoc differences between size groups in each chlorine dose were tested by one-way analysis of variance (ANOVA). All analyses were performed using a Statistical Analysis Systems package (SAS, 1985).

The data obtained on mortality of mussels at different chlorine doses were subjected to probit analysis, yielding the statistic $\mathrm{LT}_{50}$ (Litchfield and Wilcoxon, 1949).

Fig. 1. Cumulative mortality (\%) of different size groups of mussel, Brachidontes striatulus at $1 \mathrm{mg} 1^{-1}$ ( $n=12$ mussels in each size group), $2 \mathrm{mg} \mathrm{l}^{-1}$ ( $n=12$ mussels in each size group), $3 \mathrm{mg} \mathrm{1^{-1 }}$ ( $n=24$ mussels in each size group) and $5 \mathrm{mg} \mathrm{I}^{-1}(n=24$ mussels in each size group) chlorine concentrations. Mortality of $B$. striatulus was monitored at $6 \mathrm{~h}$ intervals. The criterion for mortality of mussels was shell valve gape with no response of exposed mantle tissues to external stimuli. 

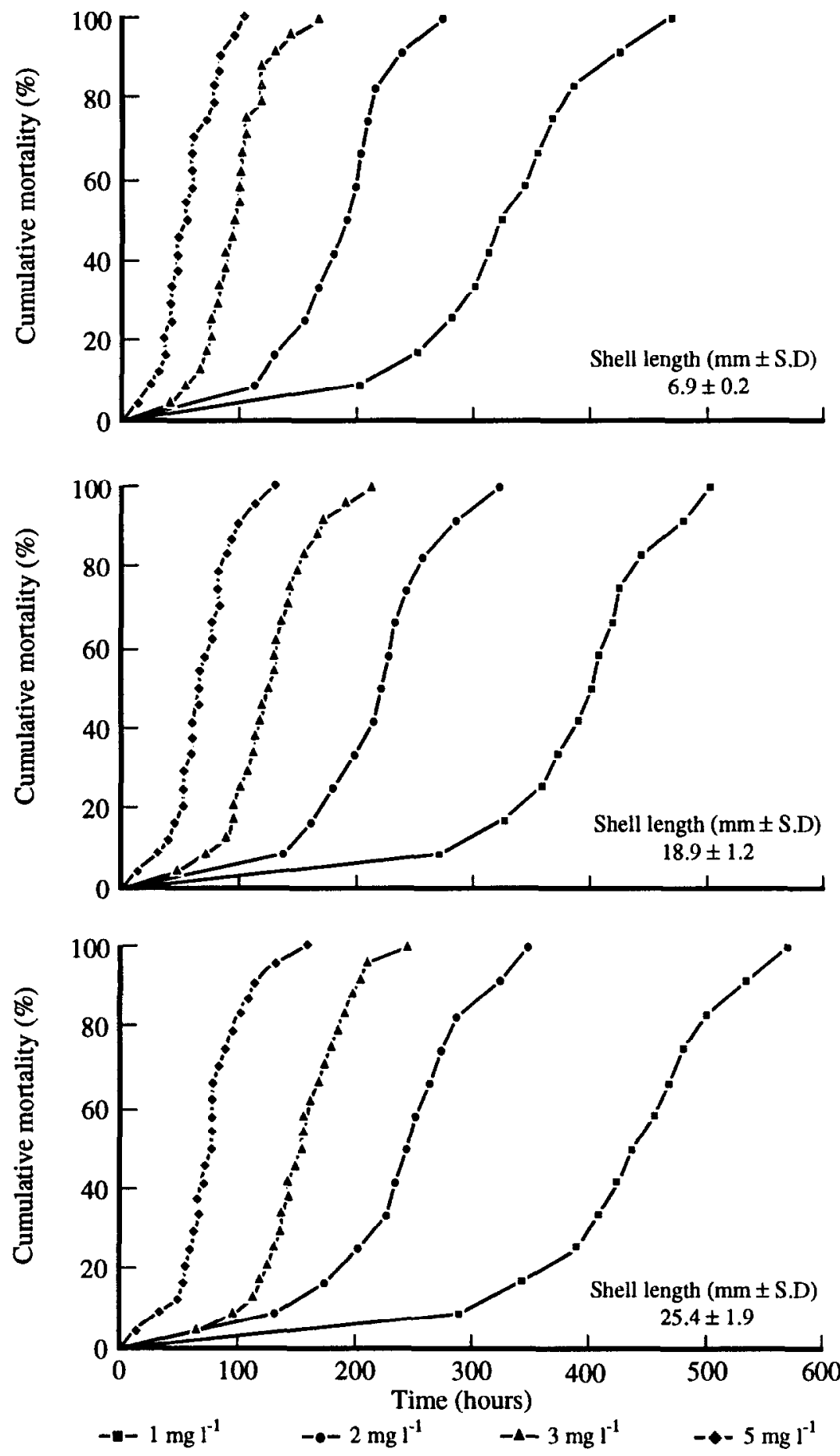




Fig. 2. Time required for $50 \%$ mortality $\left(\mathrm{LT}_{50}\right)$ of different size groups of Brachidontes striatulus at different chlorine concentrations (after probit and regression analysis). The correlation coefficient is significant to $P<0.001$ in all cases.

\section{Results}

\subsection{Mortality}

The time required for $100 \%$ mortality of $B$. striatulus exposed to different chlorine levels is presented in Fig. 1. No mortality occurred in control tanks. The three size groups (7, 19 and $25 \mathrm{~mm}$ shell length) showed $100 \%$ mortality at significantly different exposure times between 1 and $3 \mathrm{mg} \mathrm{l}^{-1}$ chlorine concentrations (mussel size effect: ANCOVA; $\left.\mathrm{F}_{(2,212)}=20.33, P<0.01\right)$. At $1 \mathrm{mg}^{-1}$ residual chlorine, 7 and $25 \mathrm{~mm}$ size group mussels took 468 and $570 \mathrm{~h}$, respectively to achieve $100 \%$ mortality (ANCOVA; $P<0.01$ ). However, at $5 \mathrm{mg} \mathrm{l}^{1}$, all size group mussels took identical exposure times to reach $100 \%$ mortality (ANCOVA; $P>0.05$ ). Moreover, mean time to death was analyzed by ANCOVA for all four concentrations of chlorine (0-5 $\left.\mathrm{mg} \mathrm{l}^{-1}\right)$ and was found to be highly significant (chlorine dose effect: ANCOVA; $\left.\mathrm{F}_{(3,212)}=837.09, P<0.0001\right)$. Comparison of means revealed that the exposure time for $100 \%$ mortality of all size groups decreased with increasing chlorine concentration (see Fig. 1).

Comparison of $\mathrm{LT}_{50}$ values of different size groups of mussels also shows that larger mussels are more resistant than smaller ones (Fig. 2). At $1 \mathrm{mg} 1^{-1}$ chlorine concentration, mussels in 7 and $25 \mathrm{~mm}$ size group took 332 and $453 \mathrm{~h}$ respectively to achieve $50 \%$ mortality. At $3 \mathrm{mg} \mathrm{l}^{-1}$, mussels in the $7 \mathrm{~mm}$ size group took $112 \mathrm{~h}$ to reach $50 \%$ mortality whereas those in the $25 \mathrm{~mm}$ size group took $165 \mathrm{~h}$ (see Fig. 2). 
Table 1

Filtration rate, foot activity index and byssus thread production of different size groups of Brachidontes striatulus at different chlorine concentrations

\begin{tabular}{|c|c|c|c|c|c|c|}
\hline \multirow[t]{3}{*}{ Chlorine dose ( $\mathrm{mg} \mathrm{l}^{-1}$ ) } & \multicolumn{3}{|c|}{ Rate of filtration ( $\mathrm{ml} \mathrm{h}^{-1}$ per mussel) } & \multicolumn{3}{|c|}{ ANOVA } \\
\hline & \multicolumn{3}{|c|}{ Size of the mussels (mm \pm S.D) } & \multirow[b]{2}{*}{$\mathrm{df}$} & \multirow[b]{2}{*}{$\mathrm{F}$} & \multirow[b]{2}{*}{$P$} \\
\hline & $7.0 \pm 0.6$ & $18.5 \pm 1.7$ & $26.0 \pm 2.3$ & & & \\
\hline Control & $19.2 \pm 3.3$ & $25.4 \pm 3.6$ & $30.2 \pm 4.9$ & 29 & 16.829 & ** \\
\hline 0.25 & $13.5 \pm 2.9^{* *}$ & $22.1 \pm 4.0^{\mathrm{ns}}$ & $28.6 \pm 3.9^{\mathrm{ns}}$ & 29 & 44.061 & ** \\
\hline 0.50 & $12.7 \pm 3.0^{* *}$ & $17.3 \pm 3.2^{* *}$ & $20.9 \pm 3.2^{* *}$ & 37 & 20.422 & ** \\
\hline 0.75 & $4.7 \pm 1.7^{* *}$ & $13.3 \pm 2.9^{* *}$ & $16.6 \pm 2.5^{* *}$ & 31 & 68.451 & ** \\
\hline 1.00 & $2.0 \pm 1.0^{* *}$ & $5.3 \pm 1.9^{* *}$ & $7.0 \pm 2.1^{* *}$ & 29 & 9.747 & ** \\
\hline 1.50 & $1.3 \pm 0.6^{* *}$ & $2.9 \pm 1.2^{* *}$ & $3.8 \pm 1.5^{* *}$ & 32 & 12.144 & ** \\
\hline
\end{tabular}

Chlorine dose $\left(\mathrm{mg}^{-1}\right) \quad$ Foot activity index (\%)

ANOVA

Size of the mussels $(\mathrm{mm} \pm$ S.D)

\begin{tabular}{|c|c|c|c|c|c|c|}
\hline & $6.2 \pm 0.4$ & $17.9 \pm 2.1$ & $25.2 \pm 1.9$ & $\mathrm{df}$ & F & $P$ \\
\hline Control & $89.6 \pm 10.6$ & $75.1 \pm 12.2$ & $69.7 \pm 8.6$ & 29 & 9.457 & $* *$ \\
\hline 0.25 & $67.4 \pm 9.8^{* *}$ & $65.4 \pm 9.0^{\mathrm{ns}}$ & $61.9 \pm 7.5^{*}$ & 29 & 0.988 & ns \\
\hline 0.50 & $42.8 \pm 7.4^{* *}$ & $49.5 \pm 6.2^{* *}$ & $40.3 \pm 6.1^{* *}$ & 31 & 5.622 & $* *$ \\
\hline 0.75 & $13.4 \pm 3.6^{* *}$ & $20.2 \pm 5.1^{* *}$ & $18.5 \pm 3.0^{* *}$ & 29 & 7.761 & $* *$ \\
\hline 1.00 & $7.3 \pm 2.2^{* *}$ & $13.7 \pm 4.2^{* *}$ & $10.9 \pm 3.1^{* *}$ & 30 & 9.598 & $* *$ \\
\hline 1.50 & $4.7 \pm 1.5^{* *}$ & $6.0 \pm 2.8^{* *}$ & $4.2 \pm 2.4^{* *}$ & 33 & 2.246 & ns \\
\hline
\end{tabular}

Chlorine dose (mg $^{-1}$ ) Byssus thread production(threads per mussel per day)

ANOVA

Size of the mussels $(\mathrm{mm} \pm$ S.D)

\begin{tabular}{|c|c|c|c|c|c|c|}
\hline & $6.5 \pm 0.9$ & $17.8 \pm 1.4$ & $25.4 \pm 1.5$ & $\mathrm{df}$ & $\mathrm{F}$ & $P$ \\
\hline Control & $89.5 \pm 14.6$ & $74.9 \pm 9.8$ & $62.9 \pm 10.1$ & 29 & 12.879 & $* *$ \\
\hline 0.25 & $68.2 \pm 8.7^{* *}$ & $70.3 \pm 9.0^{\mathrm{ns}}$ & $58.3 \pm 9.9^{\text {ns }}$ & 29 & 4.518 & $*$ \\
\hline 0.50 & $46.3 \pm 9.8^{* *}$ & $59.0 \pm 8.2^{* *}$ & $45.6 \pm 7.4^{* *}$ & 31 & 8.380 & $* *$ \\
\hline 0.75 & $15.1 \pm 5.6^{* *}$ & $26.4 \pm 6.3^{* *}$ & $22.6 \pm 5.1^{* *}$ & 29 & 11.306 & $* *$ \\
\hline 1.00 & $5.0 \pm 3.0^{* *}$ & $10.1 \pm 5.0^{* *}$ & $7.7 \pm 3.8^{* *}$ & 30 & 4.242 & $*$ \\
\hline 1.50 & $3.4 \pm 1.9^{* *}$ & $5.8 \pm 2.0^{* *}$ & $4.1 \pm 1.8^{* *}$ & 33 & 4.175 & * \\
\hline
\end{tabular}

Data are expressed as mean \pm SF. $(n=10-15)$. Differences between control and experimental mussels $\left(0.25-1.50 \mathrm{mg} \mathrm{l}^{-1}\right.$ residual chlorine) were compared by student's $t$-tests after Bonferroni's adjustment ${ }^{\mathrm{a}}$ for multiple pairwise comparisons. The posteriori differences between size groups in each chlorine dose were identified using one-way ANOVA. Significance levels are indicated by: ${ }^{*} P<0.05 ;{ }^{* *} P<0.01$; ${ }^{118}$ not significant. ${ }^{a}$ Bonferroni adjustments were carried out, taking into account, 5 tests per size group ( $n=5 ; t<3.0$ not significant; $3.00<t<3.5=P<0.05 ; t>3.5=P<0.01$ ).

\subsection{Filtration rate}

Filtration rate of mussels at different chlorine levels showed a progressive decline as the chlorine concentration increased from 0 to $1.5 \mathrm{mg}^{-1}$ (Table 1). For example, 
the $7 \mathrm{~mm}$ size group showed a decrease of filtration rate from $19 \mathrm{ml} \mathrm{h}^{-1}$ per mussel in the control to $1 \mathrm{ml} \mathrm{h}^{-1}$ per mussel at $1.5 \mathrm{mg} \mathrm{l}^{-1}(\mathrm{t}=17.590, \mathrm{df}=19, P<0.01)$, whereas the $26 \mathrm{~mm}$ size group mussels showed a decrease from $30 \mathrm{ml} \mathrm{h}^{-1}$ per mussel in the control to $4 \mathrm{ml} \mathrm{h}^{-1}$ per mussel at $1.5 \mathrm{mg} \mathrm{l}^{-1}$ residual chiorine $(\mathrm{t}=17.596, \mathrm{df}=20, P<0.01)$. There was a size-dependent variation in the filtration rate of mussels (ANOVA; control mussels; $\mathrm{df}=29, \mathrm{~F}=16.829, P<0.01$ ); with larger mussels showing higher filtration rates (Table 1 ).

\subsection{Foot activity index}

The maximum foot activity index $(90 \%)$ was observed in control experiments with $6 \mathrm{~mm}$ size group mussels (Table 1). At increased concentrations of chlorine, the foot activity index of the $6 \mathrm{~mm}$ size group tended to decrease, reaching a very low level of $6 \%$ at $1.5 \mathrm{mg}^{-1}$ of residual chlorine $(\mathrm{t}=25.004, \mathrm{df}=18, P<0.01)$. A similar pattern was evident for other size groups of mussels as well. Moreover, significant size-dependent variation in foot activity index was observed (ANOVA; control mussels; $\mathrm{df}=29, \mathrm{~F}=9.457, P<0.01$ ), i.e. foot activity index decreasing with increasing size of the mussels.

\subsection{Byssus thread production}

As in the case of the filtration rate and foot activity index, a significant sizedependent variation was observed in the byssus thread production of mussels to different concentration of chlorine (control mussels, $\mathrm{df}=29, \mathrm{~F}=12.879, P<0.01$ ). The small mussels showed higher byssus production (Table 1). Furthermore, foot activity index and byssus production of mussels were strongly correlated to chlorine concentrations (7 mm sizc group; Spcarman rank correlation test, $\mathrm{r}=0.88$, $P<0.0001$ ).

Filtration rate, foot activity index and byssus production of mussels showed reduction with increasing concentrations of chlorine (Table 1). For $18 \mathrm{~mm}$ size group mussels, filtration rate showed a reduction of $6 \%(\mathrm{t}=2.023, \mathrm{df}=18$, $P>0.05)$ and $92 \%(\mathrm{t}=19.163, \mathrm{df}=20, P<0.01)$ at 0.25 and $1.5 \mathrm{mg} \mathrm{l}^{-1}$, respectively. Similarly, at $1.5 \mathrm{mg} \mathrm{l}^{-1}$, foot activity index and byssus production showed a reduction of $92 \%(\mathrm{t}=21.736, \mathrm{df}=20, P<0.01)$ and $89 \%(\mathrm{t}=19.913, \mathrm{df}=19$, $P<0.01)$ respectively, for the same size group of the mussels. At any given chlorine concentration, filtration rate, foot activity index and byssus production were lowest in young mussels. In all size groups, physiological activities of mussels showed a strong decrease at $0.75 \mathrm{mg} \mathrm{l}^{-1}$ residual chlorine; indicating that 0.75 is the chlorine level at which activities are critically affected in $B$. striatulus.

Fig. 3. Relationship between chlorine concentrations and physiological activities of different size groups of Brachidontes striatulus (each point represents mean value of 10-15 mussels). All regression parameters are significant at $P<0.0001$. 

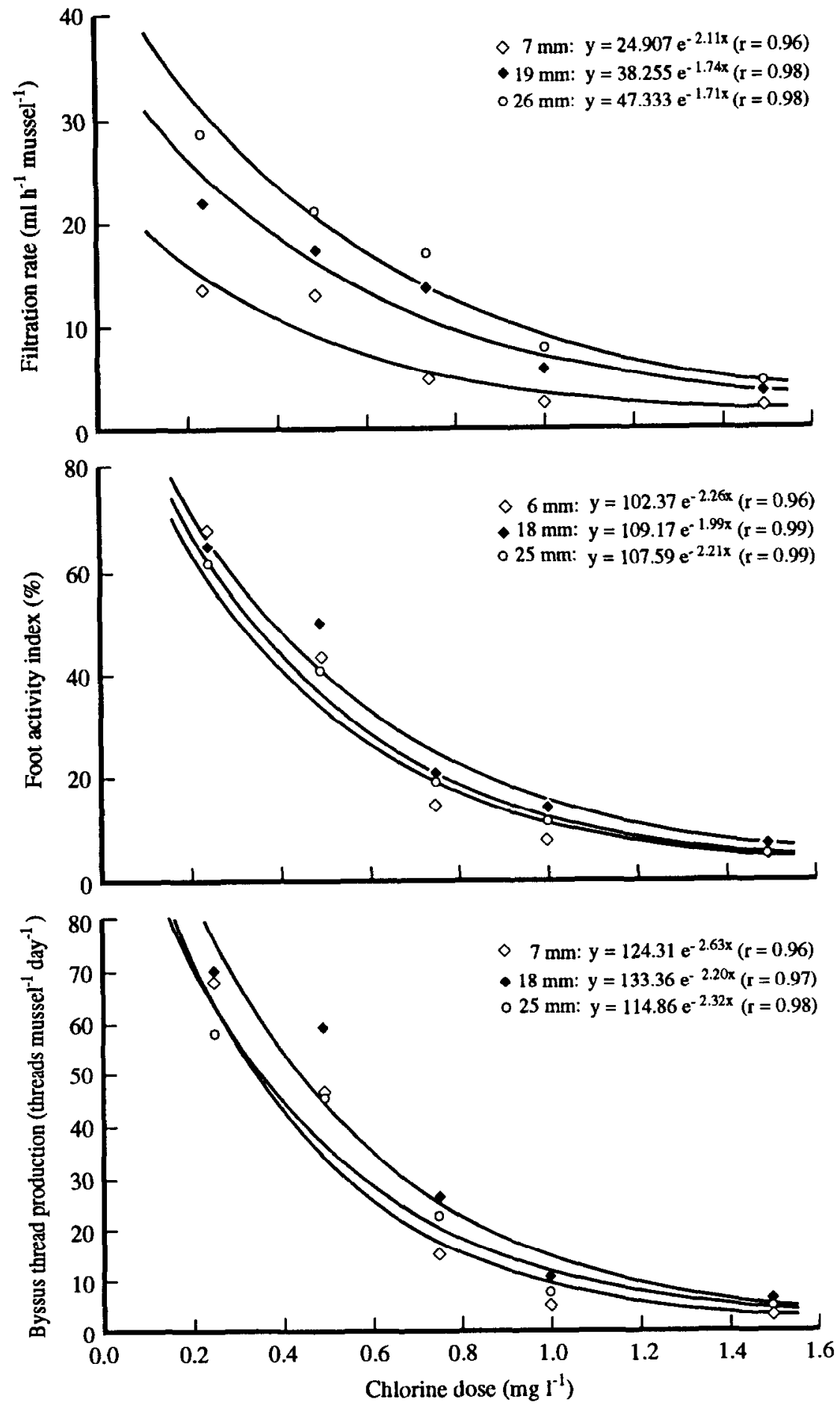
Exponential regressions of the concentration of chlorine on the sublethal responses (filtration rate, foot activity index and byssus thread production) of different size groups of mussels are shown in Fig. 3. The sublethal responses of mussels are strongly correlated with different concentrations of chlorine $(0.96<\mathrm{r}<0.99$; $P<0.0001$ ).

\section{Discussion}

Continuous application of chlorine at low-levels $\left(0.1 \mathrm{mg}^{-1}\right.$ residual chlorinc), is the most commonly used method of mussel control in cooling conduits of power stations (Jensen, 1982; Rajagopal, 1991). In India, recent studies have shown that continuous low-level chlorination $\left(0.1-0.5 \mathrm{mg} \mathrm{l}^{-1}\right)$ retards mussel settlement in the cooling systems of Madras Atomic Power Station (Rajagopal et al., 1996). Similarly, Bucaille and $\operatorname{Kim}$ (1976) observed that a chlorine level of $0.5 \mathrm{mg} \mathrm{1}^{-1}$ was enough to deter mussel settlement in a French power station. Work on larval Dreissena polymorpha (Pallas) (Benschoten et al., 1993) and Mytilus edulis L. (Lewis, 1985), has shown larval mortality occurring at residual chlorine levels as low as $0.1 \mathrm{mg}^{-1}$. However, experiments with adult mussels have indicated that a treatment with higher concentrations $\left(1 \mathrm{mg}^{-1}\right.$ total residual chlorine) will eventually kill attached mussels in the cooling conduits of power stations (Jenner, 1985; Klerks and Fraleigh, 1991; Rajagopal et al., 1996). Moreover, for a complete kill, treatment times of 1 week (Jensen, 1982) to several months will be required, depending on water temperature (Lewis, 1985; Jenner and Janssen-Mommen, 1993). The present results show that the time to $100 \%$ mortality of Brachidontes striatulus was 24 days at $1 \mathrm{mg} \mathrm{l}^{-1}, 15$ days at $2 \mathrm{mg} \mathrm{l}^{-1}$ and 10 days at $3 \mathrm{mg} \mathrm{l}^{-1}$ chlorine residuals (Table 2). The cxposurc time required for $100 \%$ mortality appears to be much lower than that reported for Perna viridis (Rajagopal et al., 1995), Mytilus edulis (James, 1967) and Mytilopsis leucophaeta (Conrad) (Rajagopal et al., 1994). However, no published results are available for $B$. striatulus to facilitate comparison with the present ones. Based on the results of this study, it seems that $B$. striatulus succumbs more easily to a given dose of chlorine, when compared to $P$. viridis, $M$. edulis and $M$. leucophaeta. The difference in tolerance among these species could be due to the different degree of their metabolic adaptations (Bayne et al., 1976). However, influence of other factors that may cause greater biocide resistance such as sex (Martin et al., 1993a), season (Jensen, 1982; Jenner, 1985) and reproductive differences (Martin et al., 1993b) cannot be discounted.

The most obvious feature of a bivalve is the protective shell. During periods of chlorination, mussels shut their valves (Khalanski and Bordet, 1980) and halt byssus production (Rajagopal et al., 1994). In doing so, they isolate their body tissues from changes in the external environment. Bayne et al. (1976) suggested that sensitive receptors on the mantle might be responsible for shell closure in mussels. The period they remained closed could last from 7 days (Jensen, 1982) to 35 days (Theede et al., 1969), with only short and intermittent periods of shell opening (Widdows, 1973; Kramer et al., 1989). Lewis (1985) noted that mussels, M. edulis 
Table 2

A summary of selected data for chlorination of various mussel species in relation to power plant biofouling control

\begin{tabular}{|c|c|c|c|c|c|c|}
\hline Species & $\begin{array}{l}\operatorname{TRC}^{\mathrm{a}} \\
\left(\mathrm{mg}^{-1}\right)\end{array}$ & $\begin{array}{l}\text { Temperature } \\
\left({ }^{\circ} \mathrm{C}\right)\end{array}$ & $\begin{array}{l}\text { Duration } \\
\text { (days) }\end{array}$ & $\begin{array}{l}\text { Mortality } \\
(\%)\end{array}$ & Comments & Reference \\
\hline \multirow[t]{8}{*}{$\begin{array}{l}\text { Dreissena poly- } \\
\text { morpha (Pallas) }\end{array}$} & 0.25 & $12-15$ & 21 & 90 & $\begin{array}{l}\text { Flow- } \\
\text { through }\end{array}$ & $\begin{array}{l}\text { Jenner and Jans- } \\
\text { sen-Mommen, } \\
1993\end{array}$ \\
\hline & 0.50 & $12-15$ & 19 & 93 & & \\
\hline & 1.00 & $12-15$ & 17 & 93 & & \\
\hline & 0.50 & $18-21$ & 9 & 100 & $\begin{array}{l}\text { Flow- } \\
\text { through }\end{array}$ & $\begin{array}{l}\text { DeGirolamo et al., } \\
1991\end{array}$ \\
\hline & 0.50 & $17-27$ & 9 & 100 & Static & $\begin{array}{l}\text { Klerks and } \\
\text { Fraleigh, } 1991\end{array}$ \\
\hline & 1.00 & $20-22$ & 20 & 80 & Static & $\begin{array}{l}\text { Martin et al., } \\
\text { 1993a }\end{array}$ \\
\hline & 2.50 & $20-22$ & 13 & 100 & & \\
\hline & 5.00 & $20-22$ & 7 & 100 & & \\
\hline \multirow[t]{4}{*}{$\begin{array}{l}\text { Mytilopsis leuco- } \\
\text { phaeta (Conrad) }\end{array}$} & 1.00 & 20 & 36 & 100 & $\begin{array}{l}\text { Flow- } \\
\text { through }\end{array}$ & $\begin{array}{l}\text { Rajagopal et al., } \\
1994\end{array}$ \\
\hline & 2.50 & 20 & 23 & 100 & & \\
\hline & 5.00 & 20 & 15 & 100 & & \\
\hline & 10.00 & 20 & 7 & 100 & & \\
\hline \multirow[t]{5}{*}{ Mytilus edulis $\mathrm{L}$. } & 1.00 & - & 39 & 100 & $\begin{array}{l}\text { Flow- } \\
\text { through }\end{array}$ & James, 1967 \\
\hline & 10.00 & - & 7 & 100 & & \\
\hline & 0.20 & 10 & 20 & 80 & $\begin{array}{l}\text { Flow- } \\
\text { through }\end{array}$ & Jensen, 1982 \\
\hline & 7.04 & 10 & 14 & 100 & & \\
\hline & 4.43 & 16.6 & 20 & 100 & $\begin{array}{l}\text { Flow- } \\
\text { through }\end{array}$ & Lewis, 1985 \\
\hline \multirow[t]{2}{*}{ Perna viridis (L.) } & 1.00 & $29-30$ & 34 & 100 & $\begin{array}{l}\text { Flow- } \\
\text { through }\end{array}$ & $\begin{array}{l}\text { Rajagopal et al., } \\
1995\end{array}$ \\
\hline & 5.00 & $29-30$ & 5 & 100 & & \\
\hline $\begin{array}{l}\text { Perna indica Kuria- } \\
\text { kose \& Nair }\end{array}$ & 1.00 & $29-30$ & 14 & 100 & $\begin{array}{l}\text { Flow- } \\
\text { through }\end{array}$ & Rajagopal, 1991 b \\
\hline $\begin{array}{l}\text { Modiolus modiolus } \\
\text { sensu auct. }\end{array}$ & 1.00 & $29-30$ & 11 & 100 & $\begin{array}{l}\text { Flow- } \\
\text { through }\end{array}$ & Rajagopal, 1991 \\
\hline \multirow[t]{3}{*}{$\begin{array}{l}\text { Brachidontes stria- } \\
\text { tulus (Hanley) }^{\mathbf{c}}\end{array}$} & 1.00 & $29-30$ & 24 & 100 & $\begin{array}{l}\text { Flow- } \\
\text { through }\end{array}$ & Present study \\
\hline & 2.00 & 2930 & 15 & 100 & & \\
\hline & 3.00 & $29-30$ & 10 & 100 & & \\
\hline
\end{tabular}

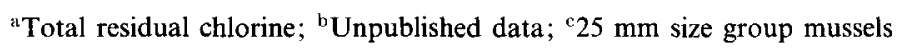

treated with chlorine residuals of $4.43 \mathrm{mg} \mathrm{l}^{-1}$ for $49 \mathrm{~h}$, were capable of making recovery within $30 \mathrm{~min}$ of exposure to ambient seawater. However, Jensen (1982) found that $M$. edulis failed to recover after a $24 \mathrm{~h}$ exposure to a chlorine residual of $8-40 \mathrm{mg} \mathrm{l}^{-1}$. A review of the literature shows that at chlorine levels below 
$1.0 \mathrm{mg} \mathrm{l}^{-1}$, mussels are able to open their valves to feed, although at a reduced rate (White, 1966; Rajagopal, 1991). However, at higher chlorine levels, they are forced to shut their valves and exist on stored food reserves and anaerobic respiration (Lewis, 1985) until energy resources are depleted or metabolic wastes reach a toxic level (Jensen, 1982). Higher chlorine residuals (i.e. $40 \mathrm{mg} \mathrm{l}^{-1}$ ) may cause denaturation of cell membranes leading to lethal effects, particularly in the gills (Opresko, 1980), but at low residuals other physiological activities are affected (Rajagopal, 1997). Therefore, experiments were conducted to ascertain the effects of chlorine administered at low-levels $\left(0.25-1.50 \mathrm{mg}^{-1}\right)$ on the physiological functions such as filtration rate, foot activity index and byssus thread production of $B$. striatulus. The present data clearly indicated that $B$. striatulus was able to sense the presence of chlorine at levels as low as $0.25 \mathrm{mg} \mathrm{l}^{-1}$ and responded by reducing the filtration rate by $6 \%$ to $30 \%$ (Table 1). Since, chlorination is done on a continuous basis, mussels do not get an opportunity to compensate for the loss incurred owing to reduced food intake (Jensen, 1982). Under such circumstances, drastic decline of the growth rate could be expected (Lewis, 1985).

To make matters worse, production of byssus thread is also affected (Table 1). Moreover, a higher percentage reduction of byssus production was observed in young mussels at all chlorine levels (Fig. 3). It is well known that young mussels are more active than older mussels and have relatively high metabolic rates (Bayne et al., 1976). Therefore, under stress, juveniles might react more rapidly than larger mussels. Differences in filtration rate among different size groups of mussels are possibly due to the variations in the gill area as reported by Jones et al. (1992). Similarly, suppression of foot activity index and reduction of byssus strength in chlorinated $M$. edulis have been reported by White (1966) who observed that mussels chlorinated at $0.2 \mathrm{mg} \mathrm{1}^{-1}$ residual level required $56 \%$ less force to detach than unchlorinated ones. Holmes (1970) also estimated that force required to detach $M$. edulis from a chlorinated cooling water system was $18-55 \%$ less than that for control mussels. Byssus inhibition by chlorine is thought to be mediated through interference in the biochemical machinery involved (Lewis, 1985). Holmes (1970) suggested that chlorine would interfere with the quinone tanning process, a vital step in the thread formation. However, further work is required to conclusively prove the mode of action of chlorine on byssus production.

Comparison of mortality data between young and adult $B$. striatulus shows that adult mussels are more resistant than young ones (Fig. 1). Therefore, it appears that when different age groups of $B$. striatulus are subjected to chlorine, it is the juveniles which are likely to get killed faster. The present chlorination regime at MAPS (lowdose continuous chlorination of $0.5 \mathrm{mg}^{-1}$ ) was originally targeted against $P$. viridis (Rajagopal et al., 1991). From the present data, it is clear that $B$. striatulus is also likely to get eliminated at the above chlorine residuals, as it is more sensitive to chlorine than $P$. viridis. 


\section{Conclusions}

1. The study showed that $100 \%$ mortality of $B$. striatulus could be achieved in 18 days at a chlorine concentration of $1 \mathrm{mg} \mathrm{l}^{-1}$. The exposure time required for $100 \%$ mortality of $B$. striatulus is much lower than that reported for some other common fouling mussels.

2. Physiological functions of the mussels are affected by chlorine in a dose-dependent fashion.

3. The study showed $0.75 \mathrm{mg} \mathrm{l}^{-1}$ to be the threshold chlorine concentration at which some of the physiological functions are critically affected.

4. Where $P$. viridis and $B$. striatulus co-exist in large numbers such as in MAPS, chlorination regime targeted against the former will also eliminate the latter.

\section{Acknowledgements}

We express our sincere thanks to Dr. P. N. Murthy, Dr. P. K. Mathur and Shri. S. B. Kuppuraju for the facilities at plant site. Thanks are also due to Prof. Dr. J. M. van Groenendael and Dr. V. P. Venugopalan for useful discussions. We would also like to thank two anonymous referees for many helpful comments and suggestions on earlier versions of the manuscript. This research was supported by funding from Council of Scientific and Industrial Research, New Delhi, India.

\section{References}

Allen, J.A., Cook, M., Jackson, J.D., Preston, S., Worth, E.M., 1976. Observation on the rate of production and mechanical properties of the byssus threads of Mytilus edulis L. Journal of Molluscau Studies 42, 279-289.

Bayne, B.L., Thompson, R.J., Widdows, J., 1976. Physiology. In: Bayne, B.L. (Ed.), Marine Mussels: Their Ecology and Physiology. Cambridge University Press, London, pp. 81-120.

Benschoten, J.E.V., Jensen, J.N., Lewis, D., Brady, T.J., 1993. Chemical oxidants for controlling zebra mussels (Dreissena polymorpha): a synthesis of recent laboratory and field studies. In: Nalepa, T.F., Schloesser, D.W. (Eds.), Zebra Mussels: Biology, Impacts and Control. Lewis Publishers, London, pp. 599-619.

Bidwell, J.R., Farris, J.L., Cherry, D.S., 1995. Comparative response of the zebra mussel, Dreissena polymorpha, and the Asian clam, Corbicula fluminea, to DGH/QUAT, a nonoxidizing molluscicide. Aquatic Toxicology 33, 183-200.

Bucaille, D., Kim, N., 1976. Influence de la chloration et du choc thermique sur les larves de Moules dans les circuits d'eau. Haliotis 7, 133-134.

Coughlan, J., 1969. The estimation of filtering rate from the clearance of suspensions. Marine Biology 2 , 356-358.

DeGirolamo, D.J., Jensen, J.N., Benschoten, J.E.V., 1991. Inactivation of adult zebra mussels by chlorine. In: American Water Works Association Annual Conference (Abstract), June 1991, Philadelphia, USA. 
Fisher, S.W., Stromberg, P., Bruner, K.A., Boulet, L.D., 1991. Molluscicidal activity of potassium to the zebra mussel, Dreissena polymorpha: toxicity and mode of action. Aquatic Toxicology 20, 219-234.

Holmes, N.J., 1970. The effects of chlorination on mussels. Report No. RD/L/R 1672, Central Electricity Research Laboratories, Leatherhead, Surrey, pp. 1-20.

James, W.G., 1967. Mussel fouling and use of exomotive chlorination. Chemistry and Industry June 17, $994-996$.

Jenner, H.A., 1985. Chlorine minimization in macrofouling control in The Netherlands. In: Jolly, R.L., Bull, R.J., Davies, W.P., Katz, S., Roberts, M.H., Jacobs, V.A. (Eds.), Water Chlorination: Chemistry, Environmental Impact and Health Effects, vol. 5. Lewis Publishers, London, pp. 1425-1433.

Jenner, H.A., Janssen-Mommen, P.M., 1993. Monitoring and control of Dreissena polymorpha and other macrofouling bivalves in The Netherlands. In: Nalepa, T.F., Schloesser, D.W. (Eds.), Zebra Mussels: Biology, Impacts and Control. Lewis Publishers, London, pp. 537-554.

Jensen, A.C., 1982. Sensitivity of Mytilus edulis (L.) to chlorination. Ph.D. thesis, Department of Oceanography, University of Southampton, England, pp. 1-159.

Jones, H.D., Richards, O.G., Southern, T.A., 1992. Gill dimensions, water pumping rate and body size in the mussel Mytilus edulis L. Journal of Experimental Marine Biology and Ecology 155, 213-237.

Khalanski, M., Bordet, F., 1980. Effects of chlorination on marine mussels. In: Jolly, R.L., Brungs, W.A., Cumming, R.B., (Eds.), Water Chlorination: Chemistry, Environmental Impact and Health Effects, vol. 3. Ann Arbor, Michigan, pp. 557-567.

Klerks, P.L., Fraleigh, P.C., 1991. Control of adult zebra mussels with sodium hypochlorite, potassium permanganate and hydrogen peroxide with iron. In: Zebra Mussels Mitigation Options for Industries (Abstract), February 1991, Toronto, Ontario, Canada.

Kramer, K.J.M., Jenner, H.A., de Zwart, D., 1989. The valve movement response of mussels: a tool in biological monitoring. Hydrobiology 188/189, 433-443.

Lewis, B.G., 1985. Mussel control and chlorination. Report No. TPRD/L/2810/R85, Central Electricity Research Laboratories, Leatherhead, Surrey, pp. 1-33.

Litchfield, J.T., Wilcoxon, F., 1949. A simplified method of evaluating dose-effect experiments. Journal of Pharmacology and Experimental Therapeutics 2, 99-113.

Martin, I.D., Mackie, G.L., Baker, M.A., 1993a. Control of the biofouling mollusc, Dreissena polymorpha (Bivalvia: Dreissenidae), with sodium hypochlorite and with polyquaternary ammonia and benzothiazole compounds. Archives of Environmental Contamination and Toxicology 24, 381-388.

Martin, I.D., Mackie, G.L., Baker, M.A., 1993b. Acute toxicity tests and pulsed-dose delayed mortality at 12 and $22^{\circ} \mathrm{C}$ in the zebra mussel (Dreissena polymorpha). Archives of Environmental Contamination and Toxicology 24, 389-.-398.

Mattice, J.S., Zittel, H.E., 1976. Site-specific evaluation of power plant chlorination. Journal of the Water Pollution Control Federation 48, 2284-2308.

Morton, B., 1977. An estuarine bivalve (Modiolus striatulus) fouling raw water supply systems in West Bengal, India. Journal of the Institution of Water Engineers and Scientists 31, 441-453.

Opresko, D.M., 1980. Review of open literature on effects of chlorine on aquatic organisms. Report No. EPRI EA-1491, Electric Power Research Institute, Palo Alto, California, pp. 1-29.

Post, R.M., Reggiani, G.M., Griffith, D.F., 1985. Evaluation of dechlorination methods for a oncethrough condenser cooling system at the Gilbert station of Jersey central power and light. In: Chow, W., Mussalli, Y.G. (Eds.), Condenser Biofouling Control: The State-of-the-Art. Electric Power Research Institute, Palo Alto, California, pp. 1 10.

Rajagopal, S., 1991. Biofouling problems in the condenser cooling circuit of a coastal power station with special reference to green mussel, Perna viridis (L.). Ph.D. thesis, University of Madras, India, pp. 1113.

Rajagopal, S., 1997. The ecology of tropical marine mussels and their control in industrial cooling water systems. Ph.D. thesis, University of Nijmegen, The Netherlands, pp. 1-184.

Rajagopal, S., Azariah, J., Nair, K.V.K., van der Velde, G., Jenner, H.A., 1996. Chlorination and mussel control in the cooling conduits of a tropical coastal power station. Marine Environmental Research 41, 201-221. 
Rajagopal, S., Sasikumar, N., Azariah, J., Nair, K.V.K., 1991. Some observations on biofouling in the cooling water conduits of a coastal power plant. Biofouling 3, 311-324.

Rajagopal, S., van der Velde, G., Jenner, H.A., 1994. Biology and control of brackish water mussel, Mytilopsis leucophaeta in the Velsen and Hemweg power stations, The Netherlands. Part II. Control measures. Report No. 163871-KES/WBR 94-3128, KEMA Environmental Services, Arnhem, The Netherlands, pp. 1-45.

Rajagopal, S., Venugopalan, V.P., Nair, K.V.K., Azariah, J., 1995. Response of green mussel, Perna viridis (L.) to chlorine in the context of power plant hiofouling control. Marine and Freshwater Behaviour and Physiology 25, 261-274.

SAS, 1985. SAS/STAT User's Guide, Release $6.03 \mathrm{edn}$. SAS Institute, Inc., Cary, NC.

Sokal, R.R., Rohlf, F.J., 1981. Biometry. W.H. Freeman \& Co., New York, pp. $1-859$.

Theede, H., Ponat, A., Hiroki, K., Schlieper, C., 1969. Studies on the resistance of marine bottom invertebrates to oxygen-deficiency and hydrogen sulphide. Marine Biology 2, 325-337.

Wallis, R.L., 1975. Thermal tolerance of Mytilus edulis of Eastern Australia. Marine Biology 30, 183191.

White, G.C., 1972. Handbook of chlorination. Van Nostrand Heinhold Company, New York, pp. 228277.

White, W.R., 1966. Effect of low-level chlorination on mussels at Poole power station. Report No. RD/L/ N 17/66, Central Electricity Research Laboratories, Leatherhead, Surrey, pp. 1-5.

Widdows, J., 1973. The effects of temperature on the metabolism and activity of Mytilus edulis L. Netherlands Journal of Sea Research 7, 387-398.

Winkle, W.V., 1970. Effects of environmental factors on byssal thread formation. Marine Biology 7, 143148.

Zar, J.H., 1984. Biostatistical Analysis, 2nd edn. Prentice-Hall Inc., Englewood Cliffs, New Jersey, pp. 1718. 